\title{
Healthcare Services Utilization among the Rural Women in Tamilnadu: A Micro Level Study
}

\author{
T. Vaidegi ${ }^{1}$, A. Abdul Raheem ${ }^{2}$ \\ ${ }^{1}$ Research Scholar (Part-Time), PG and Research Department of Economics, The New College (Autonomous), Chennai-14. \\ ${ }^{2}$ Associate Professor and Research Supervisor, PG and Research Department of Economics, The New College (autonomous), \\ Chennai-14.
}

\begin{abstract}
The health of women is inextricably linked to their responsibilities as mothers, partners, and daughters. Women are frequently the primary caregivers for their children's health and well-being, as well as their children's primary point of contact with the health-care system. Although women shoulder the majority of family healthcare responsibilities, the impact of these additional responsibilities on their health and well-being is sometimes overlooked. These responsibilities, however, are only a small part of the multiplicity of financial, family, and other obligations that women must juggle in order to satisfy their families' requirements, and many women do so in the face of adversity, such as their own health difficulties. For many women, managing family health requirements with other responsibilities is a heightened difficulty due to limited financial means, while raising children and working. But to do this, it is essential that women take charge of their health and nutritional needs. Therefore, the women are viewed as an asset to society. Women today participate in the developmental activities of the nation in large numbers. Majority of educated women are not aware of the schemes introduced by the government. Women always place the needs of their family before themselves. Therefore, the present study attempts to examine the Utilization of healthcare services among the rural women in the selected blocks of Cuddalore district, with the help of primary data, which is tested by using Percentage Analysis and Henry Garrett Ranking.
\end{abstract}

KEYWORDS: Demand for Health and Healthcare Services, Health Care System, Rural Women, Utilization of Healthcare Services.

\subsection{INTRODUCTION}

Women, who make up half of the world's population, are underutilized as human resources. Any society cannot go ahead if at least 50 percent of the population do not participate in its developmental activities. Indira Gandhi the former prime minister of India observed that neglect of women would be criminal since humanity had been deprived of half of the energy and creative talents. Women have always been treated as second-class citizens in all religions and societies throughout history. The world wars prove to be a watershed moment in human history [1]. This trend is observed in developing nations. In tune with the worldwide trend, Indian women are marching towards self-development. In India women play a secondary role for centuries together. During the colonial rule, women lived a miserable and horrible life in diverse situations [2]. Since then, women's participation in the workforce has begun to rise. Mahatma Gandhi, the Father of the Indian Nation, assisted women in reclaiming their dignity in public life, reclaiming their position in the national mainstream, and reclaiming their confidence and awareness that they could fight against injustice.

\subsection{THE ROLE OF WOMEN IN HEALTHCARE}

Most of the gender related and health related demographic researchers agree over women's pivotal role in health, as they are the keepers of a nation's health and development. When a woman is healthy, the family is healthy, the society is healthy, and the nation is healthy. By empowering women through education especially health education, the health and mortality of the people as a whole could be improved [3]. A research study shows that education in general and the women's education in particular has a positive impact on the attainment of better quality of life. Women's education is interrelated with number of health determinants like age at marriage, delay in first child birth, immunization, better household hygiene and utilization of available healthcare services. 


\title{
International Journal of Current Science Research and Review
}

\author{
ISSN: 2581-8341
}

\section{Volume 05 Issue 02 February 2022}

DOI: 10.47191/ijesrr/V5-i2-28, Impact Factor: 5.825

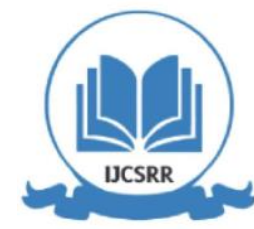

www.ijcsrr.org

Thus, the policy emphasis is now mainly on its responsibility for promoting good health through indirect means such as female education and empowerment as an educated mother is more likely to take her sick child for treatment, she is more likely to follow doctor's instruction accurately. One study says that in south India, the educated mothers are more serious about their children's sickness and use more children's health services. In every country by the end of the twentieth century, women's life expectancy had surpassed that of men. This is due to biological variations, but interactions between these differences and the physical and social environment are crucial [4]. Demand for health and healthcare services are very high for women, if they are bedridden or unable to perform their daily tasks. The women believed that most illnesses will resolve on their own. Those seeking treatment for general ailments began by trying home cures. If it didn't work, they turned to traditional healers. Those who could access care went to the nearest health facility if they were still sick. Therefore, the women are viewed as an asset to society. Women today participate in the developmental activities of the nation in large numbers. The majority of educated women are unaware of government-sponsored programmes and women always priorities their family's demands over their own. Therefore, present study attempts to analyses the Utilization of healthcare services among the rural women, with the help of primary data, which is tested by using Percentage Analysis and Henry Garrett Ranking.

\subsection{REVIEWS LITERATURE}

According to Sharma, Chandola, Singh, and Basisht [5] the necessity for preventative vs curative health care in India is largely due to the changing business environment. The changing business climate in India is largely to blame for the increased need for preventive rather than curative health care. Individual and group initiatives can increase corporate effectiveness and the quality of life for executives and employees. An infection causes severe morbidity, prolongs hospital stay, increases hospitalization costs, and contributes to mortality caused by negative septicemia, according to Mandelblatt, Cullen, Lawrence, Stanton, Yi, Kwan and Ganz [6], if the incidence and consequences of catheter-related infections are to be decreased, careful adherence to adequate infection control methods is required.

According to a study by Sarriot, Winch, Ryan, Bowie, Kouletio, Swedberg and Pacqué [7] projected 10.8 million children under the age of five die each year in underdeveloped nations from diseases that are effortlessly treatable and Nongovernmental organisations are forefront implementers of low-cost child health gains, which might be difficult to assess. Preventive medicine has evolved into a very diversified and complex medical specialty, according to Snowden, Lonnie and AnnMarie Yamada [8] the preventive medicine physicians are trained in epidemiology, biostatistics, and clinical prevention, making them uniquely qualified to work with disease, launching programmes in infectious disease prevention and control, sexually transmitted diseases, chronic disease environmental and occupational health services, administration, and as both individuals and the community to promote health and prevent prevention. They assess health dangers in the workplace using scientific methods and work to prevent occupational disease and injury.

According to Holt, Tangerine [9] indicated that the fact that many chronic diseases afflicting older people can be avoided with suitable lifestyle treatments such as frequent physical activity, people in this age range are the most sedentary in the adult population. According to Lindelow [10] the percentage of babies and children who sought medical advice in reaction to an illness was higher than that of adults. In underdeveloped nations, an individual's degree of education has a key impact in determining whether or not to seek health care; a substantial link has been discovered between low education and the lack of antenatal care. Health-care spending as a percentage of GDP fell from 1.3 percent in 1999 to 0.9 percent in 1999, according to Gupta [11]. According to the report (The Global and Mail, 2009), the proportion of people unable to access any health services doubled between 1990 and 1999 after the introduction of user fees in public healthcare, primarily among disadvantaged castes, religious minorities, and low-income people with disabilities. Only 2 percent of the nation's budget is currently spent on health care, compared to 13percent for public health, while out-of-pocket payments account for 98percent of total private health expenditure, indicating unequal access.

Poverty is also frequent in urban areas, according to Agarwal and Srivastava [12] and it is increasing as migrants migrate in from rural regions. It states that 25 percent of the 328 million people who dwell in India's urban centres live in slums. While the total yearly population growth rate in urban slums is 2 percent, the rate is 5percent, which can result in nutritional, social, and educational inequalities. Jan and Akhtar [13] found that as women's educational standing rises, their egalitarian and feminine decision-making power rises, while their family's macho and familial decision-making power declines. There are significant 


\section{International Journal of Current Science Research and Review}

ISSN: 2581-8341

Volume 05 Issue 02 February 2022

DOI: 10.47191/ijcsrr/V5-i2-28, Impact Factor: 5.825

IJCSRR@ 2022

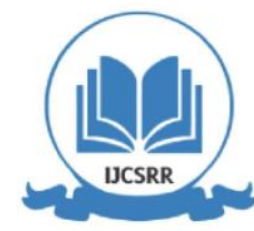

www.ijcsrr.org

disparities in decision-making capacity for family planning, control of unnatural abortions, children's health and education, involvement in local government, and choice of income-generating occupations among qualified, educated, and illiterate women. According to Ahmed, Applegate, Mitra, Callaghan-Koru, Mousumi, Khan, and Baqui [14], women had a literacy rate of 65.46 percent compared to 82.14 percent for men in the 2011 Census. The study also discovered that as maternal education improves, the kid sex ratio decreases. This indicates that highly educated women are more likely to have a sex selective abortion. This is due to the fact that these women are better off financially and can afford sex determination testing and abortions. The effects of globalization on women's status and health were studied by Wamala, and Kawachi [15]. It claims that globalization has both beneficial and bad effects on women's health, and that these effects are distributed unequally among different groups of women. For the future of globalization, the need for gender-equitable macroeconomic, trade, and labour market policies remains a top issue.

\subsection{RESEARCH METHODS}

The primary data is collected from 3 Blocks in Cuddalore District and sample selection consists of households with different income groups. A convenient sampling approach is employed to pick responders. The essential information is gathered from respondents using well-structured questionnaires. The survey is conducted on the basis of proportionate stratified random sampling method, for developing sample design, totally 250 respondents were selected for this study and the stratification is based on area and population. The simple statistical tools like Percentage Analysis. Cross tabulation, Henry Garret ranking method, Chisquare Test is used.

\subsection{UTILIZATION OF HEALTHCARE SERVICES AMONG THE AMONG THE RURAL WOMEN}

The present study attempts to analyses the Utilization of healthcare services among the rural women, with the help of primary data, which is tested by using Percentage Analysis and Henry Garrett Ranking.

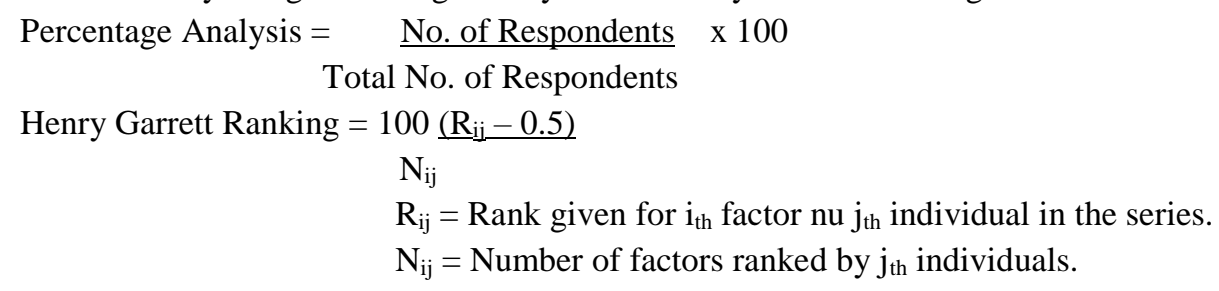

Choice of healthcare services: The table 1.1 reveals that 48 per cent of the respondents have relied on government hospitals for healthcare. Whereas 52 per cent of the respondents relied on private hospitals. This study shows that, 52 per cent of the respondents approached private hospitals for healthcare.

Table 1.1. Choice of healthcare services among the rural women

\begin{tabular}{|l|l|l|}
\hline Choice of Healthcare services & Frequency & Percentage \\
\hline Govt hospital/PHC & 120 & 48 \\
\hline Private hospital & 130 & 52 \\
\hline Total & 250 & 100 \\
\hline
\end{tabular}

Source: Primary Data

Non utilization of private hospitals: It is clear from the above table 1.2, that 3 per cent of the respondents expressed that poor treatment is a reason for Non-utilization of private hospitals, 72 per cent of the respondents expressed the reason as high expenditure, 9 per cent of the respondents expressed unsuitable timing and16 per cent of the respondents expressed advance payment is a reason for not preferring private hospitals. The table shows that majority of the respondents expressed High expenditure as a cause for not preferring private hospitals for treatment of their ailments. 


\section{International Journal of Current Science Research and Review}

ISSN: 2581-8341

Volume 05 Issue 02 February 2022

DOI: 10.47191/ijesrr/V5-i2-28, Impact Factor: 5.825

IJCSRR@ 2022

WWW.ijcsrr.org

Table 1.2. Non utilization of private hospitals

\begin{tabular}{|l|l|l|}
\hline Non - utilization of Private Hospitals & Frequency & Percentage \\
\hline Poor treatment & 04 & 03 \\
\hline High expenses & 93 & 72 \\
\hline Unsuitable timing & 12 & 09 \\
\hline Advance payment & 21 & 16 \\
\hline Total & 250 & 100 \\
\hline
\end{tabular}

Source: Primary Data

Non utilization of Government hospitals: This table 1.3 shows that 48 per cent of the respondents expressed poor treatment as a reason for not preferring government hospitals, 29 per cent of the respondents expressed Non-availability of timely service and 23 per cent of the respondents expressed Lack of cleanliness as a reason for Non-utilisation of government hospitals. The table shows that majority of the respondents expressed poor treatment as a cause for not preferring government hospitals for treatment of their ailments.

Table 1.3. Non utilization of Government hospitals

\begin{tabular}{|l|l|l|}
\hline Non - utilization of Government Hospitals & Frequency & Percentage \\
\hline Poor treatment & 58 & 48 \\
\hline Non - availability of timely service & 34 & 29 \\
\hline Lack of cleanliness & 28 & 23 \\
\hline Total & 250 & 100 \\
\hline
\end{tabular}

Source: Primary Data

Maintenance of general health: It is seen from the above table 1.4, analysis that 32 per cent of the respondents go for regular check-ups, 44 per cent of respondents the take healthy food and 24 per cent of the respondents have no idea about maintaining their health. From this study, it is found that majority of the respondents take healthy food to maintain good general health.

Table 1.4. Maintenance of general health among the rural women

\begin{tabular}{|l|l|l|}
\hline General Health & Frequency & Percentage \\
\hline Regular Check-up & 80 & 32 \\
\hline Healthy food & 110 & 44 \\
\hline No idea & 60 & 24 \\
\hline Total & 250 & 100 \\
\hline
\end{tabular}

Source: Primary Data

Type of treatment: It is seen from the above table 1.5 that 91 per cent of the respondents take English medicines, 3 per cent of the respondents take Siddha, 4 per cent of the respondents take Ayurvedic and 1 per cent of the respondents take Unani medicine. From this study, it is found that majority of the respondents take English medicines.

Table 1.5. Type of treatment adopted among the rural women

\begin{tabular}{|l|l|l|}
\hline Type of treatment & Frequency & Percentage \\
\hline English Medicine & 229 & 92 \\
\hline Siddha & 08 & 03 \\
\hline Ayurvedic & 11 & 04 \\
\hline Unani & 02 & 01 \\
\hline Total & 250 & 100 \\
\hline
\end{tabular}

Source: Primary Data 


\section{International Journal of Current Science Research and Review}

ISSN: 2581-8341

Volume 05 Issue 02 February 2022

DOI: 10.47191/ijesrr/V5-i2-28, Impact Factor: 5.825

IJCSRR@ 2022

www.ijcsrr.org

Health insurance schemes: It is identified from the above table 1.6 that 35 per cent of the respondents have taken up health insurance schemes, 65 per cent of the respondents have not taken up health insurance schemes. Majority of the respondents have not taken up health insurance schemes.

Table 1.6. Health insurance schemes taken by the rural women

\begin{tabular}{|l|l|l|}
\hline Health insurance schemes taken by respondents & Frequency & Percentage \\
\hline Yes & 87 & 35 \\
\hline No & 163 & 65 \\
\hline Total & 250 & 100 \\
\hline
\end{tabular}

Source: Primary Data

Utilization of Private Services among the rural women: Table 1.7 indicates that the factors influencing the respondents to choose the utilization of private hospital, government, and Reason for choosing the type of hospital is discussed here. In order to find out the factors influencing the women to express the utilization of private hospital government hospital, reason for choosing hospital. The respondents are asked to rank these factors. The following variables are analyzed here. Utilization of private hospital, Utilization of Government hospital and Reason for choosing the hospitals. Utilization of Private Services: From the 250 samples collected, 130 respondents have expressed preference for private health services. The respondents have ranked better services' as first with 311 as the score. Immediate treatment and attention as second with 269 as the score and Disease of major nature' as third with 200 as the score.

Table 1.7. Utilization of Private Services among the rural women

\begin{tabular}{|l|l|l|l|}
\hline $\begin{array}{l}\text { Utilization of Private } \\
\text { services }\end{array}$ & $\begin{array}{l}\text { Number of the } \\
\text { respondents }\end{array}$ & Score & Bank \\
\hline Better services & 130 & 311 & 1 \\
\hline Immediate treatment & 130 & 269 & 2 \\
\hline Disease of major nature & 130 & 200 & 3 \\
\hline
\end{tabular}

Source: Primary Data

Utilization of Government Services: From the 250 samples collected, 120 respondents have expressed preference for government health services. The respondents have ranked 'Free treatment' as first with 281 as the score. 'Better services' as second with 260 as the score and Disease of small nature' as third with 179 as the score.

Table 1.8. Utilization of Government Services

\begin{tabular}{|l|l|l|l|}
\hline $\begin{array}{l}\text { Utilization of Private } \\
\text { services }\end{array}$ & $\begin{array}{l}\text { Number of the } \\
\text { respondents }\end{array}$ & Score & Bank \\
\hline Free treatment & 120 & 281 & 1 \\
\hline Better services & 120 & 260 & 2 \\
\hline Disease of small nature & 120 & 179 & 3 \\
\hline
\end{tabular}

Source: Primary Data

Reason for choosing hospital: It could be observed from the table 1.9 that "Quality of health care' was ranked first in their choosing a hospital with a score of 1375 points. "Timely attention' was placed in the second position with a score of 1340 points. Third rank was occupied by short Distance with a score of 1185 points. 'Affordability' was placed in the fourth position with a score of 1157 points. The fifth rank was given to 'System of Medicine with a score of 983 points. "Facility is well known' was ranked sixth in their choosing a hospital list with a score of 917 points. The seventh rank is given to Elders decision with a score of 602 points. The eighth rank went to Family doctors' with a score of 468points. The main reason for respondents choosing a hospital is the "Quality of health care. 


\section{International Journal of Current Science Research and Review}

ISSN: 2581-8341

Volume 05 Issue 02 February 2022

DOI: 10.47191/ijcsrr/V5-i2-28, Impact Factor: 5.825

IJCSRR@ 2022

WWw.ijcsrr.org

Table 1.9. Reason for choosing hospital by the rural women

\begin{tabular}{|l|l|l|l|}
\hline Choosing hospital & Number of the respondents & Score & Bank \\
\hline Affordability & 250 & 1157 & 4 \\
\hline Short distance & 250 & 1185 & 3 \\
\hline Timely attention & 250 & 1340 & 2 \\
\hline Quality of healthcare & 250 & 1375 & 1 \\
\hline System of medicine & 250 & 983 & 5 \\
\hline Facility is well known & 250 & 917 & 6 \\
\hline Elders decision & 250 & 602 & 7 \\
\hline Family doctors & 250 & 468 & 8 \\
\hline
\end{tabular}

Source: Primary Data

Thus, the objective of the healthcare expenditure and utilisation of healthcare services among the rural women in the study area is identified as validated on the basis of primary data by using Percentage analysis, Henry Garret ranking method And Chi square test.

\subsection{CONCLUSION}

It could be concluded from above discussion, the Majority of the respondents have ranked Better services as the reason for utilizing private hospitals. For government hospitals 'Free treatment has been the most influencing factor. Besides, out of various factors Quality of health care is given most importance in choosing hospitals. The economic status of the women shows an association with their healthcare. Educational status has improved the healthcare of women. Although working women are aware of maintaining good health but do not go for regular check-ups due to heavy work at home and work place and less leisure time. Older women, above fifty years of age show less interest in their health due to fear of disease. Urban housewives from nuclear type of families have greater preference for private hospitals due to advanced technology, better services and treatment which gives less pain and quick relief. In spite of the charges in private hospitals bring quite high. Public hospitals are less preferred due to quality of healthcare. Therefore, the women enjoy a longer lifespan and it they must also have a possibility of enjoying a better quality of life. Women have a dual role of homecare and also society, so their health is of great importance in the development of the country. A healthy woman creates a healthy generation and a healthy generation form a more productive and developed society leading to greater development

\section{REFERENCES}

1. Raphael, D. (2006). Social determinants of health: present status, unanswered questions, and future directions. International Journal of Health Services, 36(4), 651-677.

2. Kopec, J. A., Schultz, S. E., Goel, V., \& Williams, J. I. (2001). Can the health utilities index measure change?. Medical care, 562-574.

3. Helwege, A. (1996). Preventive versus curative medicine: a policy exercise for the classroom. The Journal of Economic Education, 27(1), 59-71.

4. Basu, K. (2006). Globalization, poverty, and inequality: What is the relationship? What can be done?. World Development, 34(8), 1361-1373.

5. Sharma, H., Chandola, H. M., Singh, G., \& Basisht, G. (2007). Utilization of Ayurveda in health care: an approach for prevention, health promotion, and treatment of disease. Part 2-Ayurveda in primary health care. The journal of alternative and complementary medicine, 13(10), 1135-1150.

6. Mandelblatt, J. S., Cullen, J., Lawrence, W. F., Stanton, A. L., Yi, B., Kwan, L., \& Ganz, P. A. (2008). Economic evaluation alongside a clinical trial of psycho-educational interventions to improve adjustment to survivorship among patients with breast cancer. Journal of clinical oncology, 26(10), 1684-1690. 


\section{International Journal of Current Science Research and Review}

ISSN: 2581-8341

Volume 05 Issue 02 February 2022

DOI: 10.47191/ijesrr/V5-i2-28, Impact Factor: 5.825

IJCSRR@ 2022

www.ijcsrr.org

7. Sarriot, E. G., Winch, P. J., Ryan, L. J., Bowie, J., Kouletio, M., Swedberg, E., ... \& Pacqué, M. C. (2004). A methodological approach and framework for sustainability assessment in NGO-implemented primary health care programs. The International journal of health planning and management, 19(1), 23-41.

8. Snowden, L. R., \& Yamada, A. M. (2005). Cultural differences in access to care. Annu. Rev. Clin. Psychol., 1, $143-166$.

9. Holt, T., Wylie, A., Lee, A., Garland, E., Bordowitz, R., Hassed, C., ... \& Ilic, D. (2010). Health promotion teaching: some examples of sessions and programmes. Health Promotion in Medical Education: From Rhetoric to Action, 185.

10. Lindelow, M. (2005). The utilisation of curative healthcare in Mozambique: does income matter?. Journal of African Economies, 14(3), 435-482.

11. Gupta, K. S. (2005). Impact of globalization and liberalization on women's health in India-Future strategies.

12. Agarwal, S., \& Srivastava, A. (2009). Social determinants of children's health in urban areas in India. Journal of health care for the poor and underserved, 20(4), 68-89.

13. Jan, M., \& Akhtar, S. (2008). An analysis of decision-making power among married and unmarried women. Studies on Home and Community Science, 2(1), 43-50.

14. Ahmed, S., Applegate, J. A., Mitra, D. K., Callaghan-Koru, J. A., Mousumi, M., Khan, A. M., ... \& [118] Baqui, A. H. (2019). Implementation research to support Bangladesh Ministry of Health and Family Welfare to implement its national guidelines for management of infections in young infants in two rural districts. Journal of Health, Population and Nutrition, 38(1), 1-13.

15. Wamala, S., \& Kawachi, I. (2007). Globalization and women's health. Globalization and health, 171-13.

Cite this Article: T. Vaidegi, A. Abdul Raheem (2022). Healthcare Services Utilization among the Rural Women in Tamilnadu: A Micro Level Study. International Journal of Current Science Research and Review, 5(2), 540-546 